\title{
Regional patterns of bacterial community composition and biogeochemical properties in the southern North Sea
}

\author{
Beate Rink, Nico Grüner, Thorsten Brinkhoff, Katja Ziegelmüller, Meinhard Simon* \\ Institute for Chemistry and Biology of the Marine Environment (ICBM), University of Oldenburg, \\ 26111 Oldenburg, Germany
}

\begin{abstract}
The German Bight of the North Sea is characterized by intertidal flats, with high loads of suspended particulate matter (SPM) and estuarine inputs of organic matter, as well as pelagic offshore regions. Due to tidal and wind-induced currents, the hydrography of this area is highly dynamic. In order to examine how these properties affect the regional distribution and composition of the bacterioplankton we conducted 2 surveys, in June 2002 and June 2003; in these surveys we assessed the composition of the free-living (FL) and particle-associated (PA) bacterial communities together with hydrographic properties (salinity, temperature) and biogeochemical properties (SPM, particulate organic carbon, chlorophyll, phytoplankton composition). The bacterial community composition was determined by denaturing gradient gel electrophoretic (DGGE) analysis of 16S rRNA gene fragments, PCR-amplified by Bacteria-, Alphaproteobacteria- and Bacteroidetes-specific primer sets, and sequencing of excised bands. The results, and a multidimensional scaling (MDS) analysis of the DGGE banding patterns, showed distinct differences in the bacterial community composition of the FL and PA fractions and also between the inshore and offshore stations. A canonical correspondence analysis (CCA), including the DGGE banding patterns, temperature, salinity and biogeochemical parameters, further showed that the community patterns and the inshore and offshore gradients can be explained to a great extent by the hydrographic and biogeochemical conditions. Several prominent bands, identified as phylotypes affiliated to the Roseobacter clade, persisted throughout all 10 stations visited, whereas other phylotypes occurred only at distinct stations, inshore and offshore.
\end{abstract}

KEY WORDS: Free-living and attached bacteria - DGGE - Phytoplankton - Suspended matter · Chlorophyll $\cdot$ MDS analysis

\section{INTRODUCTION}

Marine ecosystems are structured in the open sea and coastal environments - including the mesohaline to polyhaline estuarine regions - and they exhibit different hydrographic and biogeochemical properties. Dissolved and particulate organic matter are key biogeochemical components in these regions and are decomposed by complex communities of free-living (FL) and particleassociated (PA) heterotrophic bacteria (Cotner \& Biddanda 2002). It has been shown that the origin and composition of the organic matter, and the availability of inorganic nutrients, affect the composition and growth of bacterial communities (Lebaron et al. 1999, Covert \& Moran 2001, Pinhassi et al. 2006, Alonso-Sáez et al. 2007, Alonso-Gutiérrez et al. 2009). Both FL and PA bacterial communities are important in the turnover of organic matter in estuarine and coastal systems, and the diversity of these subcommunities has been studied extensively (Crump et al. 1999, Fandino et al. 2001, Dang \& Lovell 2002, Selje \& Simon 2003, Crump et al. 2004, Stevens et al. 2005a, Rink et al. 2007).

In the coastal regions of the southern North Seathe German Bight — high loads of dissolved and partic- 
ulate inorganic and organic matter are introduced from the Wadden Sea intertidal flats and the Rivers Weser and Elbe, thus providing organic and inorganic nutrients as well as refractory organic matter (Loewe et al. 2005, Lübben et al. 2009). Current patterns and water masses are highly variable in this shallow region - in which water depths are 10 to $40 \mathrm{~m}$ - even though, in general, currents from the southwestern North Sea move water masses into this area and continue northwards as the Jutland current towards the Skagerrak (Becker et al. 1992, Staneva et al. 2009).

Various aspects of the North Sea bacterioplankton have been studied; for example, the culturability of pelagic bacteria (Eilers et al. 2001), seasonal and interannual dynamics of bacterioplankton communities and of specific phylogenetic groups (Eilers et al. 2000, Gerdts et al. 2004, Rink et al. 2007, Sapp et al. 2007) and the composition of bacterioplankton communities as a function of respiration and growth (Reinthaler et al. 2005). The RCA (Roseobacter Clade Affiliated) cluster has been identified as a prominent fraction of the Roseobacter clade in the North Sea (Selje et al. 2004, Giebel et al. 2011). However, the spatial distribution of the bacterial community, e.g. inshore and offshore gradients, including the intertidal flats and pelagic regions, has not been examined. It is not known how the diversity of the bacterial communities varies within and among the various bodies of water mentioned above. Possibly, the diversity varies as a result of the patchy distribution of phytoplankton blooms, the strong tidal currents, and the strong gradients of suspended particulate matter (SPM) (Staneva et al. 2009); alternatively, the strong currents within the German Bight, and the generally shallow water depth, may lead to a well-mixed situation, preventing the establishment of pronounced regional differences in the bacterial community composition. Obtaining insight into regional patterns in the composition of bacterial communities is also important for designing sampling strategies for future investigations; appropriate strategies may be able to link the composition of the community to hydrographic and biogeochemical processes, not only in the German Bight, but also in other shallow coastal regions exhibiting strong currents and estuarine and terrestrial inputs of dissolved and particulate matter.

We investigated the bacterial communities, together with SPM and phytoplankton properties, at various inshore and offshore stations in the German Bight in June 2002 and June 2003. We focused on the following 2 questions: (1) Is the composition and richness of the FL and PA bacterial communities at the SPM-rich inshore stations different when compared to the composition and richness of these communities at the offshore stations, and, if so, is such a difference related to the SPM proper- ties? (2) Do systematic differences exist between the richness of the Bacteroidetes phylum and Alphaproteobacteria in the FL and PA bacterial communities, and are the distribution patterns of both subcommunities related to SPM properties? We used denaturing gradient gel electrophoresis (DGGE) of 16S rRNA gene fragments and applied primer sets specific for Bacteria, Alphaproteobacteria and the phylum Bacteroidetes to examine the composition of these communities; we also used statistical tools - canonical correspondence analysis (CCA) and multidimensional scaling (MDS) - to evaluate distribution patterns and their relationships to biogeochemical and hydrographic properties.

\section{MATERIALS AND METHODS}

Study area and sampling methods. Surface water samples were collected with a 101 Niskin bottle at various locations in the German Bight, southern North Sea, from 11 to 13 June 2002 and 24 to 27 June 2003 (Fig. 1, Table 1) on board RV 'Heincke'. For analysis of SPM dry weight, particulate organic carbon (POC), and chlorophyll a (chl a), 500 to $1000 \mathrm{ml}$ of sample water were filtered, in duplicate, through precombusted and preweighed glass-fiber filters (GF/F, Whatman) and stored at $-20^{\circ} \mathrm{C}$ in the dark until further processing in the laboratory within $4 \mathrm{wk}$. For enumeration of bacteria, $100 \mathrm{ml}$ of seawater were fixed with formaldehyde $(2 \% \mathrm{v} / \mathrm{v})$ and stored at $4{ }^{\circ} \mathrm{C}$ until further processing within $4 \mathrm{wk}$. Phytoplankton cells were fixed with Lugol's solution as described elsewhere (Utermöhl 1958). For DGGE analyses, $250 \mathrm{ml}$ of sample water were fractionated by filtration through polycarbonate filters (Nuclepore) of pore sizes 5.0 $\mu \mathrm{m}$ (PA bacteria) and subsequently $0.2 \mu \mathrm{m}$ (FL bacteria) and stored at $-20^{\circ} \mathrm{C}$ until further processing within 4 mo. Temperature and salinity were recorded by a built-in probe aboard the RV 'Heincke'.

Enumeration of bacteria and algae. Bacteria were counted using epifluorescence microscopy after staining with 4',6-diamidino-2-phenylindole (DAPI) on black $0.2 \mu \mathrm{m}$ Nuclepore filters at $1000 \times$ magnification (Porter \& Feig 1980). We analyzed 1 sample from each station and did not differentiate between FL and PA cells, mainly because it was rather difficult to reliably enumerate particle-associated cells in samples from the inshore stations, which had high concentrations of SPM. At the time of this study, the reliable desorption technique of PA bacteria by Lunau et al. (2005) was not yet available. Phytoplankton cells were counted by inverted microscopy (Utermöhl 1958), and phytoplankton species were identified according to Drebes (1974).

Phytoplankton pigments, SPM and POC. For the analysis of chlorophyll, filters were extracted at $75^{\circ} \mathrm{C}$ in 


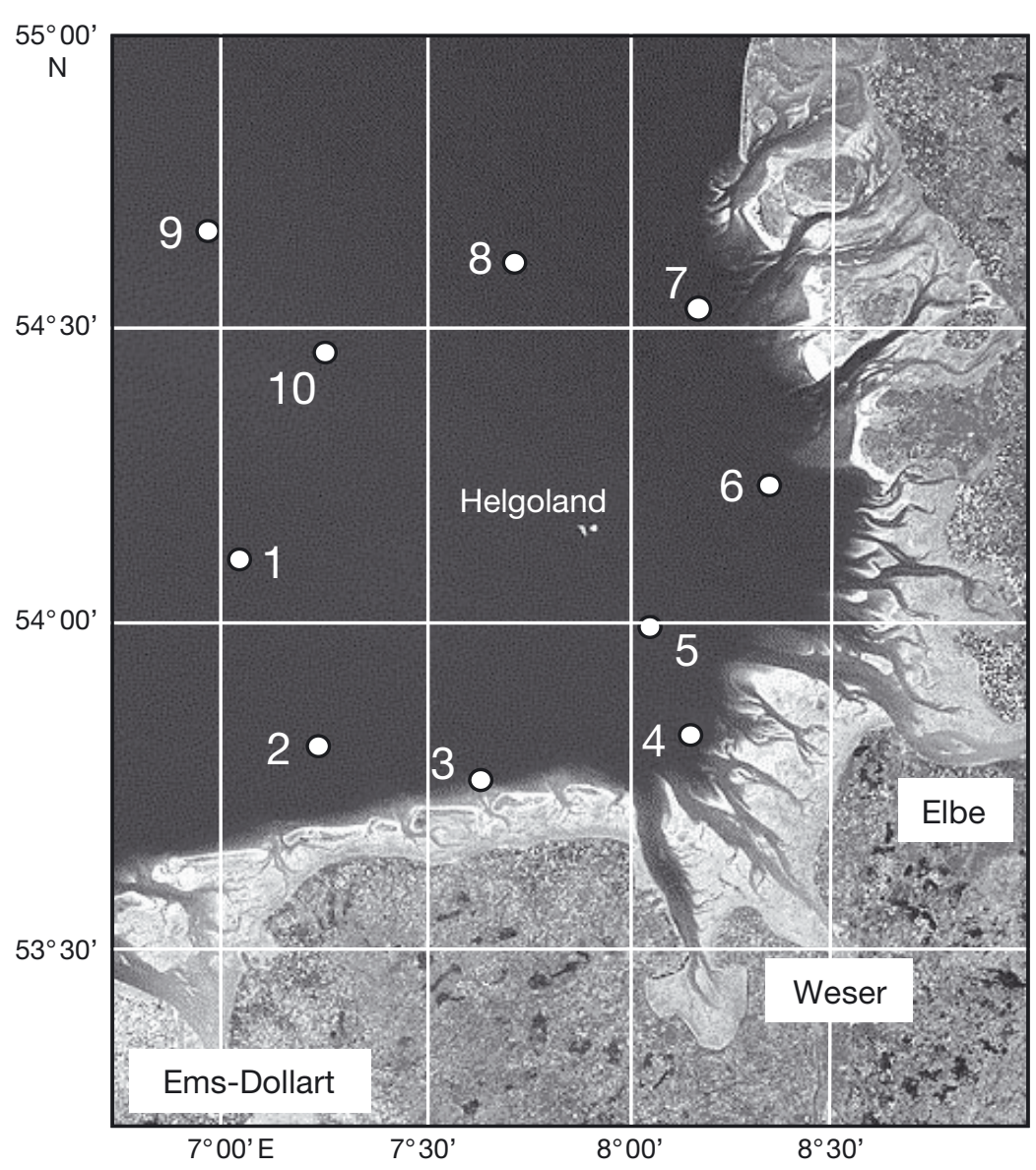

Fig. 1. Study area and locations of the sampling stations (Nos. 1 to 10) in the German Bight, southern North Sea

Table 1. Sampling stations, location, water depth and days of sampling

\begin{tabular}{|c|c|c|c|c|c|}
\hline \multirow[t]{2}{*}{ Stn } & \multirow{2}{*}{$\begin{array}{l}\text { Latitude } \\
\left({ }^{\circ} \mathrm{N}\right)\end{array}$} & \multirow{2}{*}{$\begin{array}{l}\text { Longitude } \\
\left({ }^{\circ} \mathrm{E}\right)\end{array}$} & \multirow{2}{*}{$\begin{array}{l}\text { Water depth } \\
\qquad(\mathrm{m})\end{array}$} & \multicolumn{2}{|c|}{ Days of sampling } \\
\hline & & & & June 2002 & June 2003 \\
\hline 1 & $54^{\circ} 07.98^{\prime}$ & $7^{\circ} 04.64^{\prime}$ & 32 & 13 & 26 \\
\hline 2 & $53^{\circ} 49.69^{\prime}$ & $7^{\circ} 15.31^{\prime}$ & 18 & 12 & 26 \\
\hline 3 & $53^{\circ} 48.33^{\prime}$ & $7^{\circ} 38.45^{\prime}$ & 8 & 12 & 27 \\
\hline 4 & $53^{\circ} 52.95^{\prime}$ & $8^{\circ} 05.24^{\prime}$ & 8 & 13 & 24 \\
\hline 5 & $53^{\circ} 59.58^{\prime}$ & $8^{\circ} 03.52^{\prime}$ & 8 & 13 & 24 \\
\hline 6 & $54^{\circ} 13.91^{\prime}$ & $8^{\circ} 20.66^{\prime}$ & 11 & 11 & 25 \\
\hline 7 & $54^{\circ} 32.08^{\prime}$ & $8^{\circ} 10.98^{\prime}$ & 9 & 11 & 25 \\
\hline 8 & $54^{\circ} 36.88^{\prime}$ & $7^{\circ} 42.26^{\prime}$ & 17 & 11 & 25 \\
\hline 9 & $54^{\circ} 38.44^{\prime}$ & $6^{\circ} 56.41^{\prime}$ & 36 & 11 & 26 \\
\hline 10 & $54^{\circ} 28.15^{\prime}$ & $7^{\circ} 15.05^{\prime}$ & 29 & 11 & 26 \\
\hline
\end{tabular}

$90 \%$ ethanol and concentrations of chl a were determined spectrophotometrically (Nusch 1999). For phaeopigment determination, samples were acidified with $\mathrm{HCl}(2 \mathrm{~N})$ prior to spectrophotometric analysis. For determination of SPM, filters were dried for $1 \mathrm{~h}$ at $110^{\circ} \mathrm{C}$ and weighed on a micro-balance (Sartorius). In 2002, SPM was corrected for salt according to Lunau et al. (2006), and in 2003 filters were rinsed with distilled
$\mathrm{H}_{2} \mathrm{O}$. POC was determined with a FlashEA 1112 CHN-analyzer (Thermo Finnigan).

Nucleic acid extraction, primer sets and PCR amplification of 16S rRNA gene fragments. Genomic DNA was extracted with phenol-chloroform as described in Rink et al. (2007) with slight modifications. DNA was precipitated at $-20^{\circ} \mathrm{C}$ overnight using isopropanol and resuspended in molecular grade water. Samples were stored at $-20^{\circ} \mathrm{C}$ until further processing. For amplification of $16 \mathrm{~S}$ rRNA gene fragments, the primer sets targeted DNA of Bacteria (primer pair GC 341F, Muyzer et al. 1993; 907RM, Muyzer et al. 1998), the Bacteroidetes phylum (primer pair GC CF319aF, Jaspers et al. 2001, and 907RM), and Alphaproteobacteria (primer pair GC 341F and ALF 968R, Rink et al. 2007). The specificity of the primer sets and the applied PCR conditions are described by Rink et al. (2007). Amplification products were analyzed by electrophoresis in $1.5 \%(\mathrm{w} / \mathrm{v})$ agarose gels and stained with ethidium bromide $\left(1 \mu \mathrm{g} \mathrm{ml}^{-1}\right)$ (Sambrook et al. 1989). For subsequent sequence analysis, PCR products were purified with the Qiaquick PCR purification kit (Qiagen).

DGGE and cluster analysis. DGGE was performed with an INGENYphorU system (Ingeny International BV) following the protocol of Rink et al. (2007). After electrophoresis, the gels were stained with SYBR Gold (Molecular Probes) and documented using a BioDoc Analyze Transilluminator (Biometra). Bands were excised, suspended in $50 \mu \mathrm{l}$ of water (molecular grade, Eppendorf) and stored at $-20^{\circ} \mathrm{C}_{i} 1 \mu \mathrm{l}$ was used as template in subsequent PCR. A cluster analysis of the DGGE banding patterns was performed using the software GelCompare II, Version 2.5 (Applied Maths). We applied 5 to $20 \%$ background subtraction depending on the signal-to-noise ratio of the corresponding gel. Patterns were compared curve-based using Pearson's correlation as similarity coefficient and the unpaired group method of analysis (UPGMA) to generate the dendrogram. We used the position tolerance optimization option of the software to fit the curves to the best possible matching. 
Cloning. 16 DGGE bands were cloned using the pGEM $^{\circledR}$-T Vector System II (Promega) following the instruction manual. At least 5 clones with inserts from each DGGE band were picked after blue-white screening and amplified with the specific DGGE primers. The fragment length of the inserts was screened by agarose gel electrophoresis, and positive inserts were examined for their identity using DGGE. Adequate clones were amplified for sequencing using the primers pUC/M13f and pUC/M13r (Sambrook et al. 1989).

Sequencing and phylogenetic analysis. PCR products were sequenced with an Automated DNA Sequencer (Model 4200, LI-COR) using the primers $341 \mathrm{~F}$ and $907 \mathrm{RM}$, labeled with IRDye ${ }^{\mathrm{TM}} 800$, and the DYEnamic Direct cycle sequencing kit (Amersham Life Science). Clones were sequenced by Geneart using the primer M13f. At least $400 \mathrm{bp}$ were determined for all sequences and the phylogenetic affiliation was compared to those in GenBank using the BLAST function of the NCBI server (www.ncbi.nlm. nih.gov). The phylogenetic trees were constructed using the ARB software package (www.arb-home.de, Ludwig et al. 2004). The backbone tree was calculated with the maximum likelihood method using sequences with a minimum of $1300 \mathrm{bp}$ length, including type strains of the selected phylogenetic groups. To avoid uncertain alignments, we excluded positions at which less than $50 \%$ of all sequences showed the same residues. Sequences with less than 1300 bp were added to the backbone tree with the maximum parsimony method using the same filter. 16S rRNA gene sequences of 7 type strains belonging to Cyanobacteria were used as the outgroup.

Data analysis. For MDS analysis, DGGE banding patterns were transformed into binary code scored as present (scored as 1) or absent (scored as 0). Distance matrices for all pair-wise combinations were constructed using the Jaccard coefficient and used as input for the MDS and for hierarchical clustering. Clustering was performed to identify groups of related sampling stations. To compare the DGGE banding patterns of the stations of each data set, every data set of the clustering was normalized to the highest distance found by this algorithm (the distance where all stations are identified as one cluster). Clusters (ellipses in Figs. 5 \& 6) were then composed of stations with a normalized similarity of at least $75 \%$. The MDS was performed with MatLab R2009a (MathWorks), including the statistics toolbox.

The CCA was applied to the measured hydrographic and biogeochemical parameters and the DGGE banding patterns for every sample. The CCA was performed with Brodgar Version 2.6.6 (Highland Statistics).
Nucleotide sequence accession number. The sequences obtained in this study are available from GenBank under accession nos. DQ911759 to DQ911821.

\section{RESULTS}

\section{Hydrography}

In both years (2002 and 2003), the offshore stations with depths $\geq 17 \mathrm{~m}$ (Stns 1, 8, 9, 10) were characterized by lower water temperatures and higher salinities when compared to the inshore stations (Stns 2 to 7 , Fig. 2). At the latter stations, the water depth is only 8 to $11 \mathrm{~m}$ except at Stn 2, whose properties are more offshore than inshore (see 'Concentration and composition of SPM' below). At the shallow inshore stations water was well mixed, whereas at the offshore stations the water column was stratified. Temperature and salinity were higher in 2003 compared to 2002, when the survey was carried out 2 wk earlier.

\section{Concentration and composition of SPM}

In both years, concentrations of SPM were higher at the inshore stations compared with the offshore stations, including Stn 2 (Fig. 3A,B). POC, measured only in 2003, varied from $0.10 \mathrm{mg} \mathrm{C} \mathrm{l^{-1 }}$ at Stn 9 to $0.78 \mathrm{mg} \mathrm{Cl}^{-1}$ at Stn 6 , with generally higher values at the inshore stations compared to the offshore stations

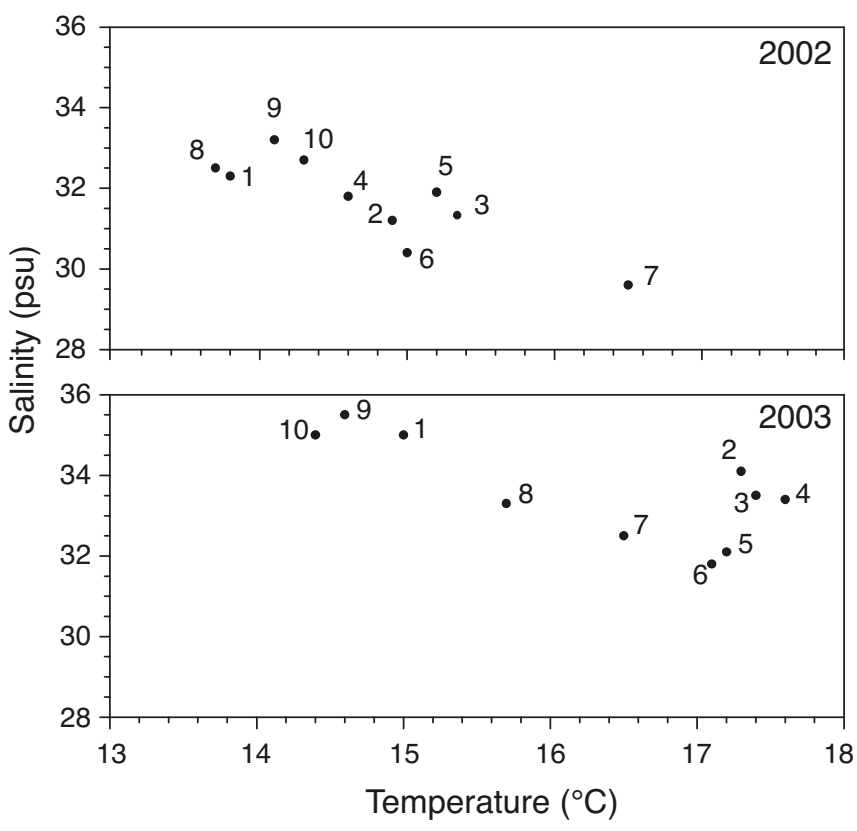

Fig. 2. Temperature versus salinity at the sampling stations in the German Bight in June 2002 and June 2003. For exact locations and dates see Fig. 1 and Table 1 

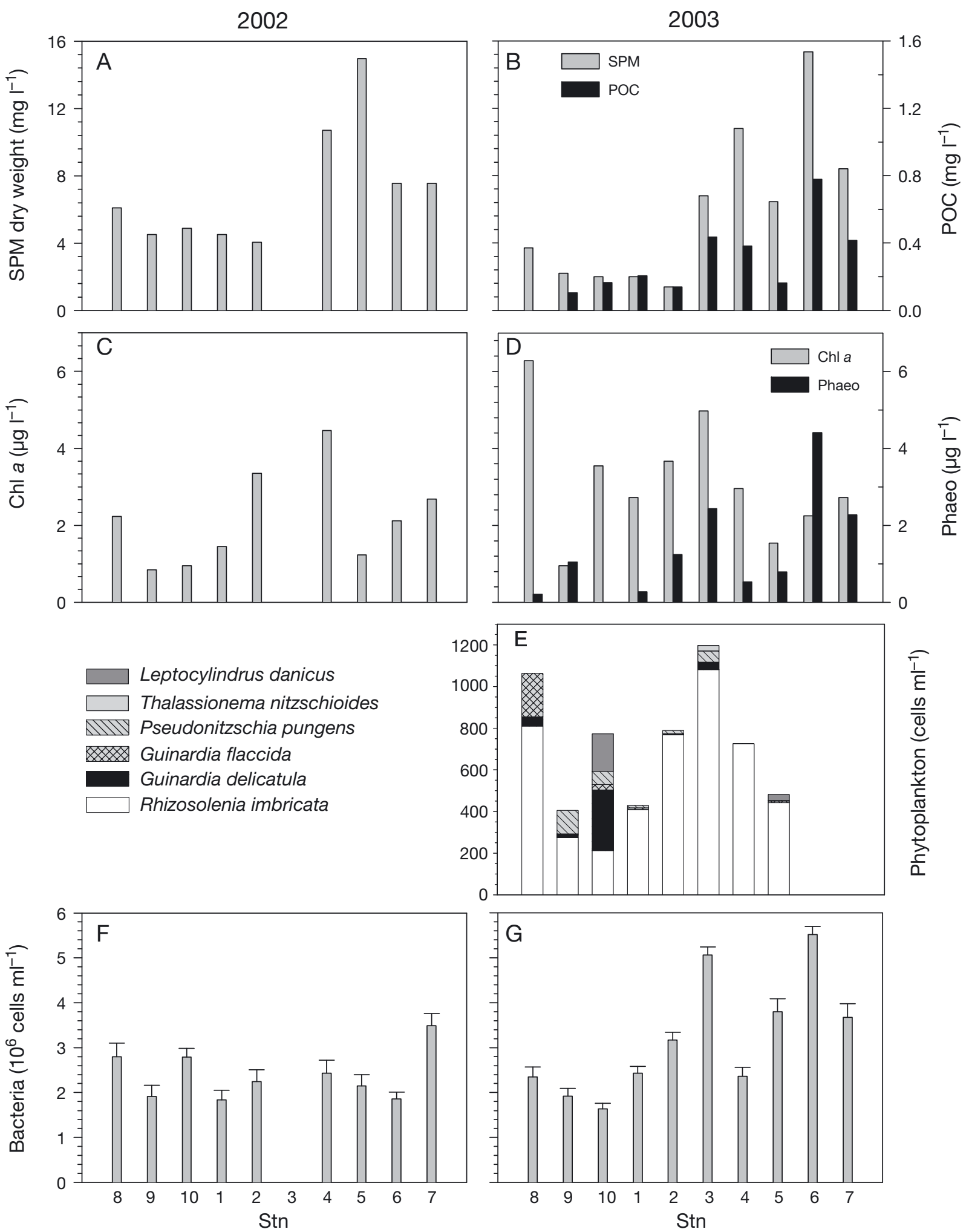

Fig. 3. (A) Suspended matter (SPM) dry weight in 2002; (B) SPM and particulate organic carbon (POC) in 2003; (C) chlorophyll a (chl a) in 2002; (D) chl $a$ and phaeopigments (phaeo) in 2003; (E) phytoplankton cell numbers in 2003; (F) bacterial numbers in 2002; and (G) bacterial numbers in 2003 at various stations in the German Bight. Error bars are \pm SD. Samples were collected in June of both years. Stns 8 to 10 and 1 are offshore, Stns 2 to 7 are inshore. For exact locations and dates see Fig. 1 and Table 1. Missing bars indicate that data are not available 
(Fig. 3B). At Stns 2, 9 and 10, POC constituted around $10 \%$ of SPM dry weight, but at the inshore stations it was generally $<6 \%$.

\section{Chl a and phytoplankton}

Concentrations of chl a were rather variable in both years, with no clear-cut differences between the inshore and offshore stations (Fig. 3C,D). In 2002, the highest concentrations occurred at Stns 2 and 4, and the lowest concentrations were at Stns 5, 9 and 10. In 2003, the concentrations were highest at Stns 3 and 8, and the lowest were at Stns 5 and 8 . The patterns of phaeopigment concentration, available only for 2003, were quite different from those of chl a (Fig. 3D), indicating that the growth phase - and thus the physiological status of the phytoplankton - was quite variable among the stations. The highest proportions of phaeopigments (percentage of chl $a+$ phaeopigments), close to, or exceeding, those of chl $a$, occurred at Stns 6,7 and 9. In 2002, Leptocylindricus danicus dominated the phytoplankton at the offshore stations, and Rhizosolenia imbricata was dominant at the inshore stations (data not shown). At the North Frisian coast (Stns 6 and 7), Guinardia delicatula and Guinardia flaccida were also present in substantial proportions. In 2003, the phytoplankton at all stations was greatly dominated by $R$. imbricata, except at Stn 10, which showed a more diverse composition, including substantial proportions of Guinardia spp. (Fig. 3E). Phytoplankton cell numbers generally reflected concentrations of chl $a$, with the highest values at Stns 3 and 8. At Stns 6 and 7 the high sediment load in the samples prevented reliable enumeration.

\section{Bacterial abundance}

In 2002, bacterial abundance varied between $1.8 \times$ $10^{6}$ cells ml ${ }^{-1}$ at Stn 1 and $3.5 \times 10^{6}$ cells ml ${ }^{-1}$ at Stn 7 (Fig. 3F). Numbers did not co-vary with chl a or SPM. In 2003, the offshore stations exhibited low bacterial numbers; the highest numbers were recorded at Stns 3 and 6, together with high concentrations of chl $a$ and SPM (Fig. 3G).

\section{DGGE banding patterns and bacterial community analysis}

Pronounced differences were detected between DGGE banding patterns of FL and PA bacterial communities assessed by Bacteria-, Bacteroidetes- and Alphaproteobacteria-specific primers as shown by the DGGE banding patterns and cluster analysis (see Figs. S1 to S3 in the supplement at www.int-res.com/articles/suppl/ a063p207_supp.pdf) as well as by the MDS analysis (see below). Sequencing revealed that 10 out of 21 excised bands of the Bacteria-specific and 1 out of 10 of the Bacteroidetes-specific 16S rRNA gene amplicons of the PAassociated fractions were of plastid origin. These bands were not considered for further analyses. The Bacteriaspecific primer set yielded 11 to 18 DGGE bands of the FL bacterial community at single stations in 2002, out of a total of 21 bands, and 10 to 20 bands in 2003 out of a total of 24 bands (Fig. 4, Table 2). In 2002, the lowest number of bands occurred at Stn 8 and the highest number at Stn 4, whereas in 2003, the lowest number was recorded at Stn 2 and the highest number at Stns 6 and 7. Two
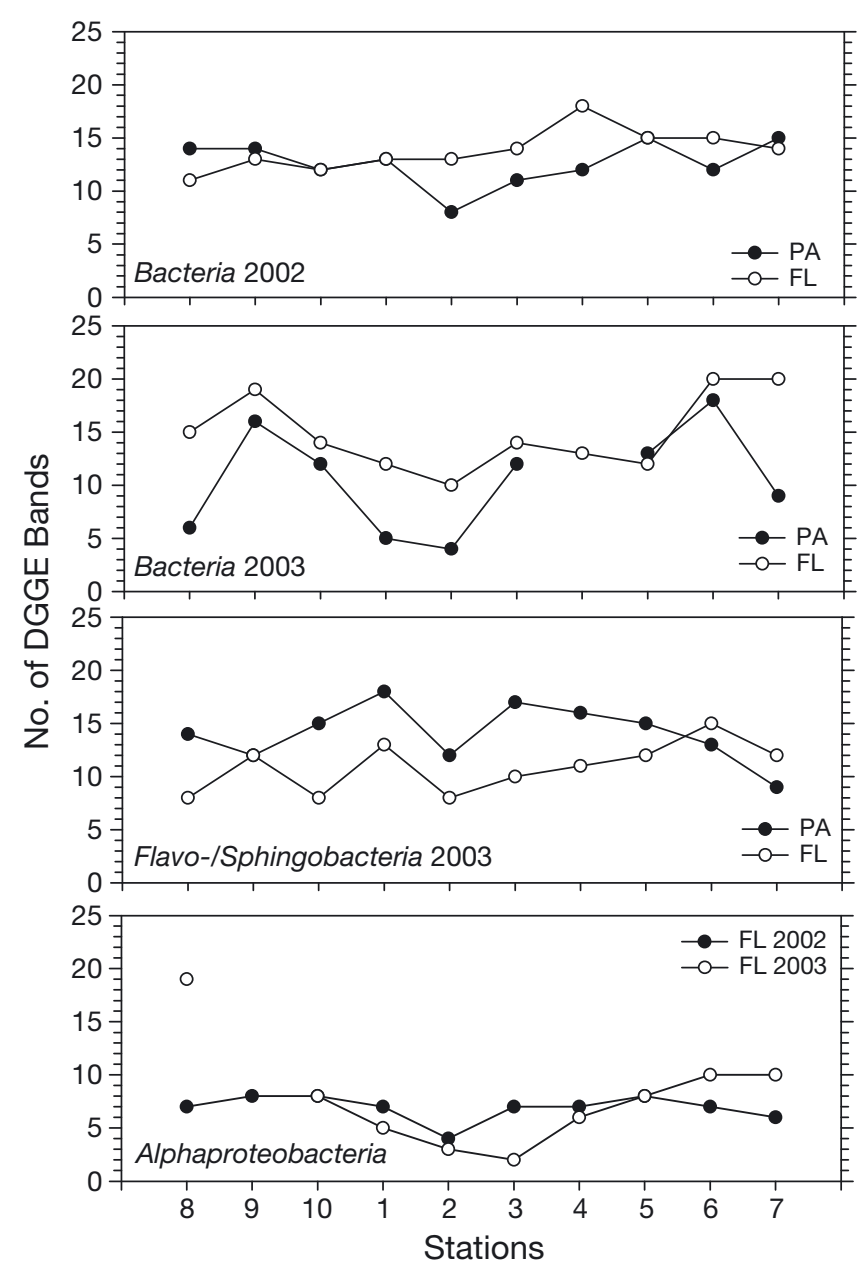

Fig. 4. Number of bands detected in the DGGE analyses of free-living (FL) and particle-associated (PA) bacterial communities using primer sets specific for Bacteria in 2002 and 2003, for Flavobacteria/Sphingobacteria in 2003, and for FL-Alphaproteobacteria in 2002 and 2003 at various stations in the German Bight (point for Stn 9 is missing in 2003). Samples were collected in June of both years. Stns 8 to 10 and 1 are offshore, Stns 2 to 7 are inshore. For exact locations and dates see Fig. 1 and Table 1. For banding patterns see Figs. S2 \& S3 in the supplement 


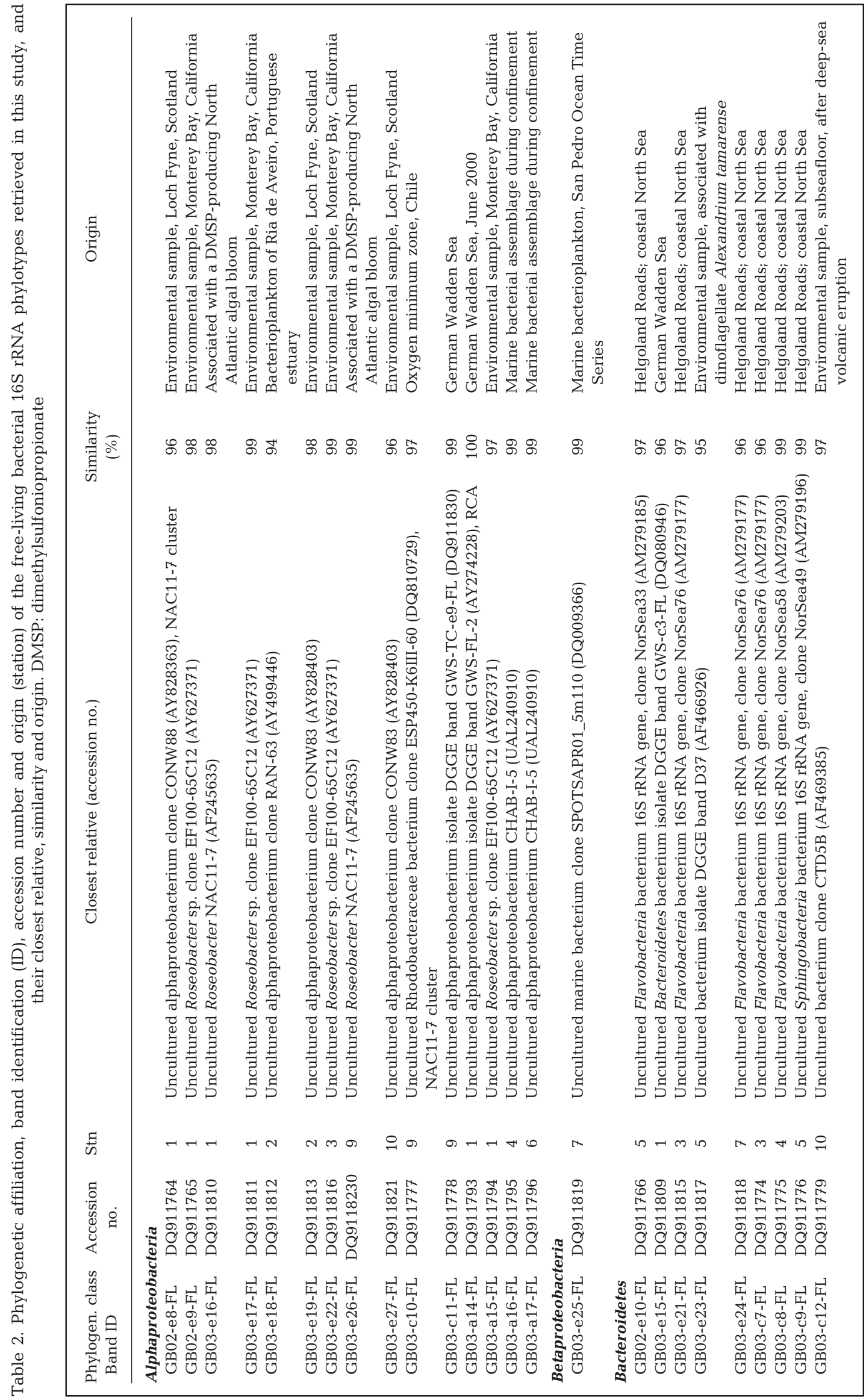




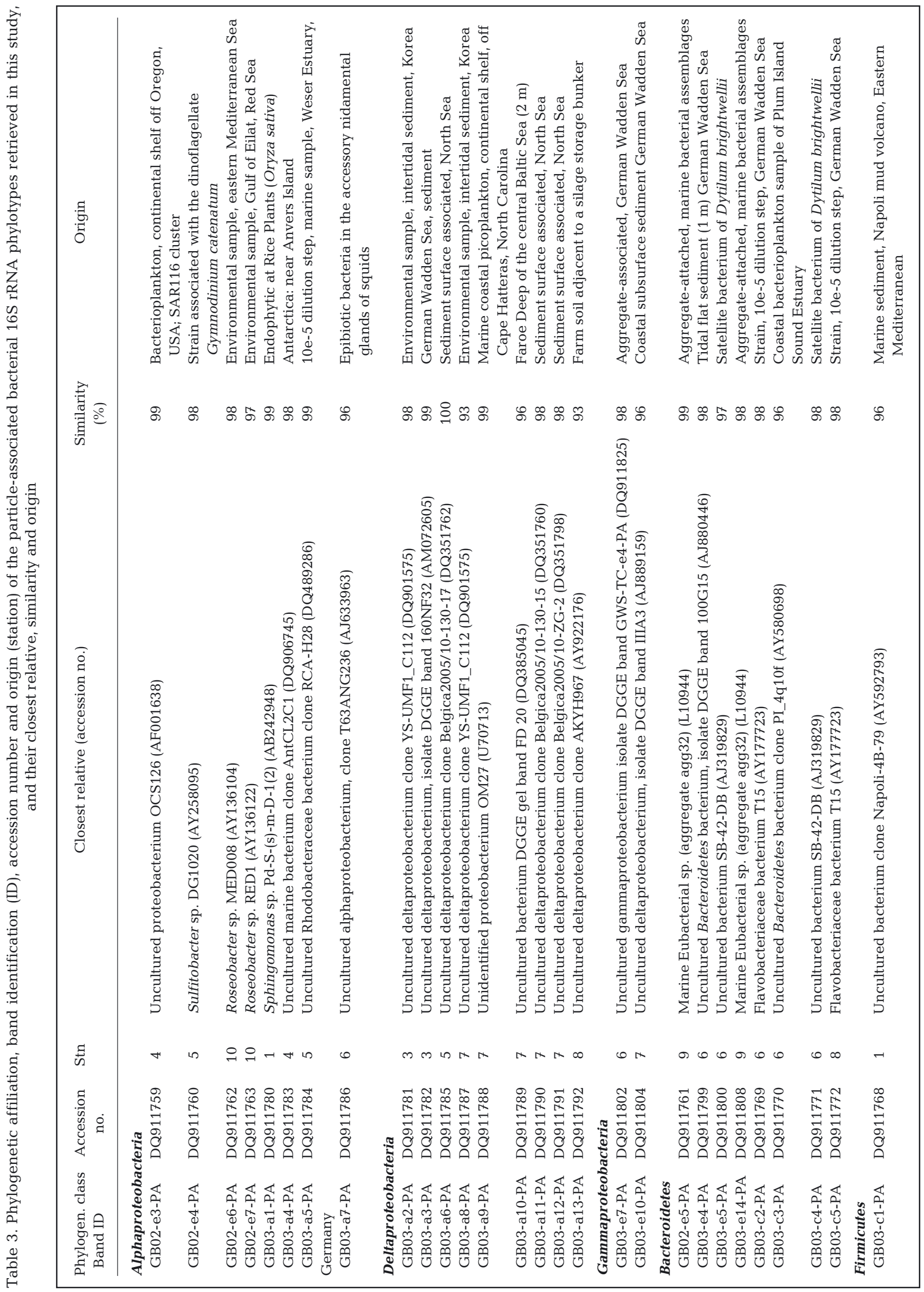


prominent bands persisted throughout all stations in both years; they were identified as clones GB02-e8-FL, GB02-e9-FL, GB03-e16-FL and GB03-e17-FL (Table 3). Other bands occurred at only a few stations, or individual stations, such as at Stns 1 and 10 (GB03-e15-FL), 6 and 7 (GB03-e24-FL, GB03-e25-FL), and 5 (GB03e23-FL). In 2003, Stns 6 and 7 exhibited distinctly different patterns compared with the other stations (see Figs. S2 \& S3).

The richness, i.e. number of DGGE bands, in the PA and FL bacterial communities of the Bacteria-specific 16S rRNA gene amplicons was rather variable in 2002 (Fig. 4). In 2003, however, the richness of the PA relative to the FL bacterial community was lower at 8 out of
10 stations (Fig. 4, for Stn 4 no data are available), and the mean richness of the former community was significantly lower (Student's $t$-test, $\mathrm{p}<0.05$ ).

The MDS analysis revealed similarities among the FL and PA bacterial communities, in the various water masses. In 2002, the FL bacterial communities at the inshore stations, and at the southernmost offshore station (Stns 1 to 7), as well as offshore Stns 9 and 10, grouped closely together (Fig. 5A). The PA bacterial communities in this year exhibited different clusters. Those at inshore Stns 4 to 6, and at Stn 8, grouped together (Fig. 5B), as did those at the southwestern Stns 1, 2 and 3 and at the offshore Stns 9 and 10. In 2003, the FL bacterial communities at the westernmost
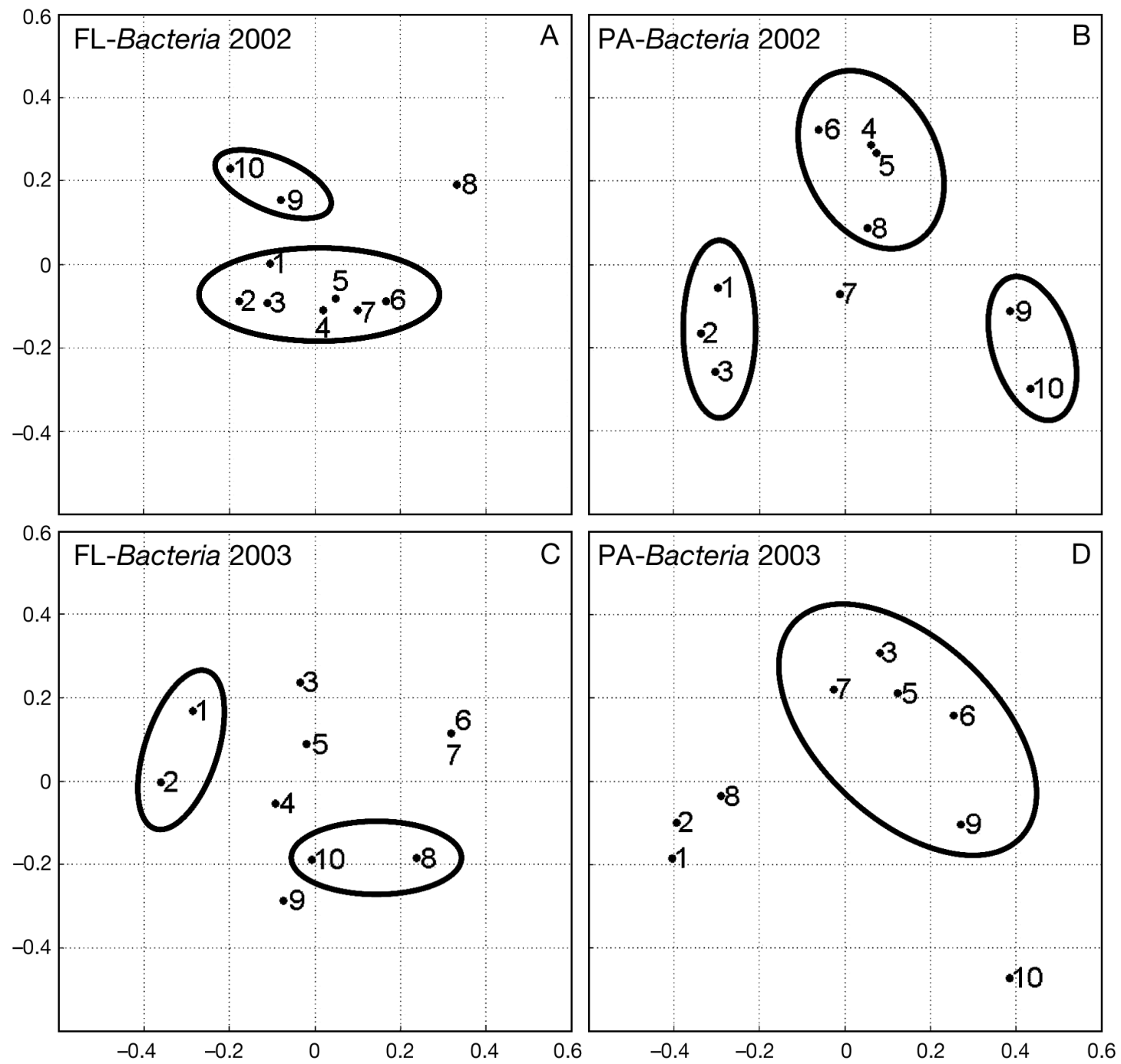

Fig. 5. Multidimensional scaling (MDS) maps of denaturing gradient gel electrophoresis (DGGE) banding patterns of free-living (FL) and particle-associated (PA) bacterial communities detected with Bacteria-specific primer sets at various stations in the German Bight in June 2002 and 2003. (A) FL-Bacteria in 2002. (B) PA-Bacteria in 2002. (C) FL-Bacteria in 2003. (D) PA-Bacteria in 2003. Numbers next to the black dots refer to stations from which samples originate. Stns 8 to 10 and 1 are offshore, Stns 2 to 7 are inshore. For exact locations and dates see Fig. 1 and Table 1. Clusters of a similarity of at least $75 \%$ normalized to the total distance of all DGGE banding patterns of a given data set are encircled 
Stns 1 and 2, and at the offshore Stns 8 and 10, grouped together and formed a different cluster, compared with the inshore stations, which did not group together but showed station-specific properties (Fig. 5C). In contrast, the PA bacterial communities at inshore Stns 3 to 7 (Stn 4 was not included in the analysis) and Stn 9 also grouped together, whereas the PA bacterial communities at the offshore stations and Stn 2 did not show any grouping (Fig. 5D).

DGGE analysis of the FL and PA bacterial communities, applying the Bacteroidetes-specific primer set, was done only in 2003. The results revealed pronounced differences between both subcommunities, with a higher richness in the PA bacterial community at 7 out of 10 stations (Figs. $4 \& \mathrm{~S} 1$ to S3, Tables $2 \& 3$ ).
In the FL bacterial community, between 8 bands (Stns 2, 8, 10) and 15 bands (Stn 6) were detected, and in the PA bacterial community between 9 bands (Stn 7) and 18 bands (Stn 1) were detected. A few bands in the PA, but not in the FL, fraction of this bacterial subcommunity were detected at all stations (e.g. GB03-c2-PA) but others occurred only at individual stations, such as at Stns 1 to 5 and 8 (GB03-c5-PA, Table 3), at Stns 2 to 5 (GB03-c8-FL, Table 2), and at Stns 1, 8 and 10 (GB03-c12-FL).

In the MDS analyses, the banding patterns of the FL communities of the Bacteroidetes phylum at inshore Stns 4 to 7 grouped closely together (Stn 3 was not included in the MDS analysis), as did those of offshore Stns 9 and 10 (Fig. 6A). The patterns of
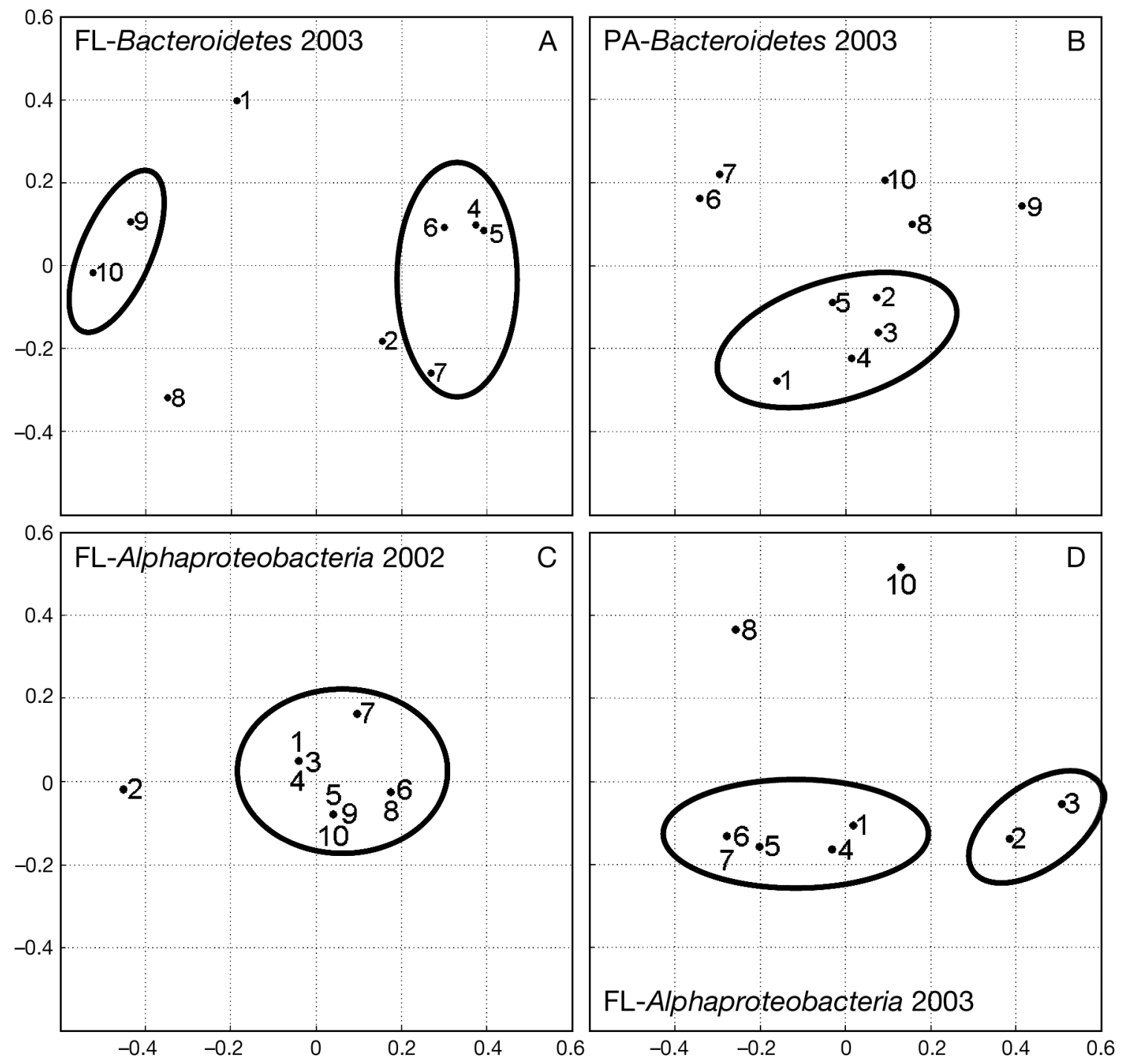

Fig. 6. Multidimensional Scaling (MDS) maps of denaturing gradient gel electrophoresis (DGGE) banding patterns of free-living (FL) and particle-associated (PA) bacterial communities detected with Bacteroidetes- and Alphaproteobacteria-specific primer sets at various stations in the German Bight in June 2002 and 2003. (A) FL-Bacteroidetes in 2003. (B) PA-Bacteroidetes in 2003. (C) FL-Alphaproteobacteria in 2002. (D) FL-Alphaproteobacteria in 2003. Details are as in Fig. 5 
the PA-associated Bacteroidetes communities were slightly different as only southern and western inshore Stns 2 to 5, but also Stn 1, grouped together. The other inshore and offshore stations did not show any grouping (Fig. 6B).

The Alphaproteobacteria-specific DGGE banding patterns revealed the lowest band numbers of all the target groups, with 4 to 8 bands in the FL bacterial community in 2002, and 2 to 10 bands in 2003, except at Stn 8, where 19 bands were detected at a pronounced bloom of Rhizosolenia imbricata, Guinardia delicatula and Guinardia flaccida (Figs. 3 \& 4). In the PA subcommunity of Alphaproteobacteria, 3 to 12 bands were detected in 2002 and 9 to 16 bands in 2003 . Sequencing revealed that the banding patterns of the PA Alphaproteobacteria were highly biased by nonspecific amplifications of other proteobacterial $16 \mathrm{~S}$ rRNA phylotypes. Only 4 of the 13 bands sequenced affiliated to Alphaproteobacteria. The banding pattern of the FL community was rather variable, but 2 conspicuous bands (GB-a14-FL, GB-a15-FL, Table 2) occurred at all stations.

The MDS analysis did not detect any clear-cut separation of the FL alphaproteobacterial subcommunities at the inshore and offshore stations in 2002 because nearly all stations, except Stn 2, grouped closely together (Fig. 6C). In 2003, however, banding patterns of the inshore Stns 4 to 7 , but also including that of offshore Stn 1, grouped together, as did those of Stns 2 and 3 (Fig. 6D). Because of the bias of non-specific amplifications, no MDS analysis of the PA alphaproteobacterial community was performed.

\section{Phylogenetic affiliation}

Sequencing of the excised DGGE bands obtained from the Bacteria-specific amplicons showed that 12 bands out of a total of 38 contained chloroplast-derived 16S rRNA gene fragments. Ten of them were detected in the PA fraction. In addition, 13 sequences affiliated to Alphaproteobacteria, 1 to Betaproteobacteria, 2 to Gammaproteobacteria and 10 to the Bacteroidetes phylum.

All sequences of Alphaproteobacteria obtained from the Bacteria-specific DGGE gels affiliated to the Roseobacter clade, except GB02-e3-PA (Stn 4), which was related most closely to Acidiphilium aminolytica (Tables 2 \& 3, Fig. S4A in the supplement). The phylotypes occurring at all stations in both years (GB02-e8FL, GB03-e16-FL, GB02-e9-FL and GB03-e17-FL) affiliated to the NAC11-7 cluster detected first in the North Atlantic (González et al. 2000) and the WM11-36 cluster identified in the polyhaline section of the Weser estuary (Selje \& Simon 2003).
The 2 clones which affiliated to Gammaproteobacteria (GB03-e7-PA, GB03-e10-PA) were detected in 2003 in the PA bacterial community of Stn 6 and were closely related to clones from the East Frisian Wadden Sea (GWS-AG-6, GWS-SE-4, Fig. S4C).

Sequences of DGGE bands obtained with the Bacteroidetes-specific primer set revealed 4 non-specific amplifications. DGGE band GB03-c1-PA (Stn 1, PA fraction) was related to a Firmicutes species (Table 3), band GB03-c6-PA to chloroplast-derived 16S rRNA genes, bands GB03-c10-FL and GB03-c11-FL to an uncultured member of the Rhodobacteraceae and an uncultured $\alpha$-Proteobacterium. The sequences of 2 DGGE bands obtained from the PA fraction of Stn 6 (GB03-c3-PA and GB03-c4-PA) were closely related to 16S rRNA gene fragments detected as a diatom-associated bacterium and in coastal bacterioplankton (GWSAG-8, GWS-c2-FL, Fig. S4D), respectively. Clone GB03-c2-PA (Stn 6) was closely related to strain T15, isolated from a high-dilution step of a dilution culture from the East Frisian Wadden Sea (Brinkhoff et al. 2004).

Sequencing of $16 \mathrm{~S}$ rRNA gene fragments obtained from the Alphaproteobacteria-specific DGGE gel showed non-specific amplification in the PA bacterial community. Nine of the 13 sequences obtained were identified as Deltaproteobacteria predominantly originating from sediments, and only 4 as Alphaproteobacteria (Fig. S4A,B, Table 3). Two of them affiliated to the Roseobacter clade, to the RCA cluster (GB03-a5-PA) and to Sulfitobacter pontiacus (GB-a4-PA), and the other two to Rhodobacterales (GB-a7-PA) and the genus Sphingomonas (GB03-a1-PA), respectively. The 4 sequenced bands of the FL bacterial community of the Alphaproteobacteria-specific DGGE gel affiliated to the clusters RCA (GB03-a14-FL) and WM11-36 (GB03-a15-FL, GB03-a16-FL) of the Roseobacter clade, and one closely to a phylotype retrieved from the German Wadden Sea and related to Acidiphilum aminolytica (GB03-a17-FL).

\section{CCA of the DGGE banding patterns, hydrographic and SPM-related biogeochemical properties}

The data set of 2002 exhibited close positive correlations between DGGE patterns, i.e. richness (number of bands), of FL Bacteria and chl $a$, between richness of PA-Alphaproteobacteria, SPM and temperature, and of FL-Alphaproteobacteria and salinity (Fig. 7A). Negative correlations existed between the richness of PA-Bacteria and FL-Bacteria and between that of FLAlphaproteobacteria and PA-Alphaproteobacteria, chl $a$, SPM and temperature. In 2003, close positive correlations were found between the richness of FL- 

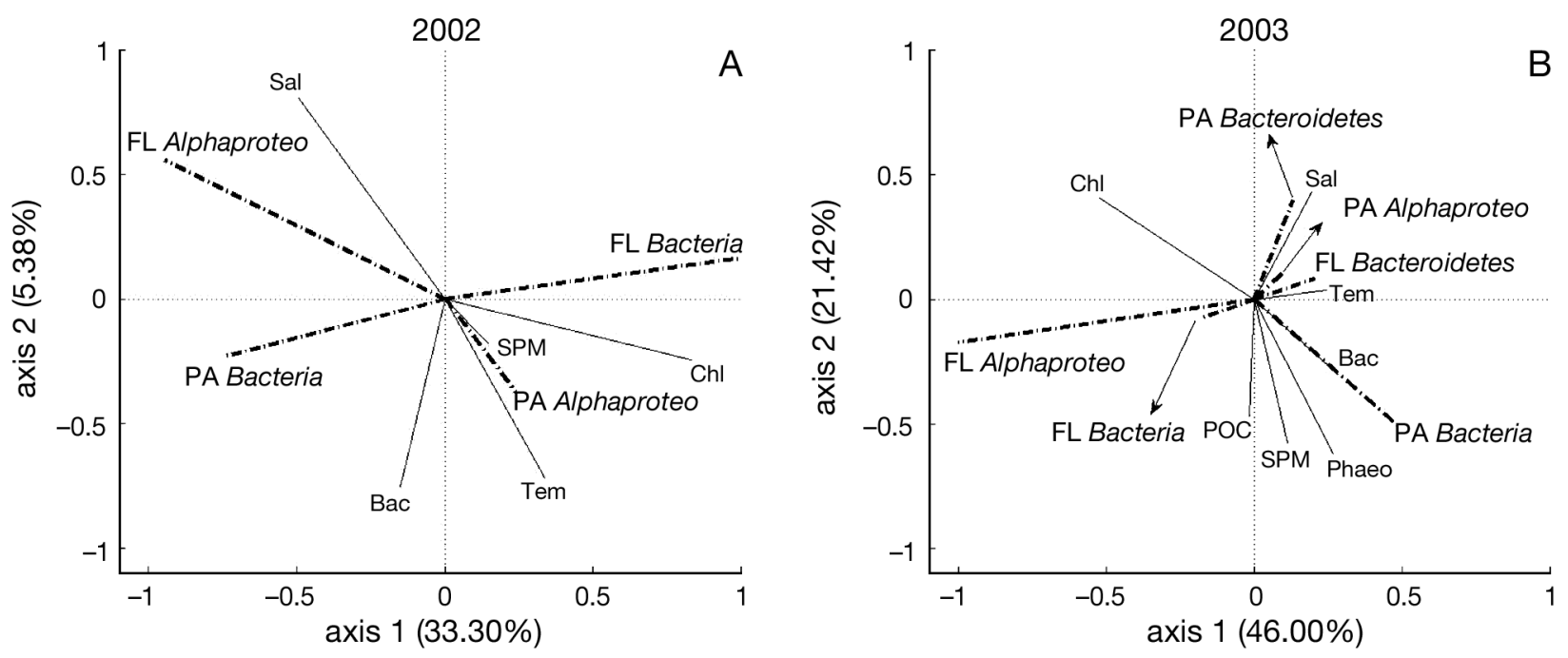

Fig. 7. Canonical correspondence analysis (CCA) with data sets including denaturing gradient gel electrophoresis (DGGE) banding patterns of free-living (FL) and particle-associated (PA) bacterial communities detected with various primer sets; salinity (Sal), temperature (Tem), suspended particulate matter (SPM), particulate organic carbon (POC), bacterial numbers (Bac), chlorophyll a (Chl) and phaeopigments (Phaeo) at various stations in the German Bight in (A) June 2002 and (B) June 2003. The thicker dashed lines represent data of the DGGE analyses

Bacteria and FL-Alphaproteobacteria, between that of PA-Bacteria, bacterial numbers, phaeopigments and SPM, between that of FL-Bacteroidetes, PA-Alphaproteobacteria and salinity, and between that of PABacteroidetes, PA-Alphaproteobacteria and salinity (Fig. 7B). In contrast, the richness of FL-Alphaproteobacteria was negatively correlated to that of FLBacteroidetes and temperature, that of PA-Bacteria negatively to chl $a$, and that of FL-Bacteria negatively to FL-Bacteroidetes and temperature.

\section{DISCUSSION}

\section{Spatial patterns of FL and PA bacterial communities and correlation to environmental and SPM-related biogeochemical properties}

Systematic spatial patterns in the composition of marine bacterial communities have been reported from estuarine salinity gradients (Crump et al. 1999, Selje \& Simon 2003, Hewson \& Fuhrman 2004) and across oceanic water masses with distinct hydrographic properties (Baldwin et al. 2005, Giebel et al. 2009) but not yet from regional seas such as the German Bight of the North Sea with its rather variable and small-scale hydrographic properties (Becker et al. 1992, Staneva et al. 2009). Our results and, in particular, the MDS analysis of the DGGE banding patterns, show that differences in the composition of FL as well as PA bacterial communities existed between the offshore and shallow (i.e. $<11 \mathrm{~m}$ deep) SPM-rich inshore stations. The inshore stations of both subcommunities grouped together more consistently than did the offshore stations. The fact that several bacterial ribotypes of both subcommunities were detected exclusively at inshore or offshore stations further indicates differences between both regions. On the other hand, various DGGE bands of both subcommunities were present at all stations, indicating that several populations persisted in the German Bight, irrespective of the given hydrographic and biogeochemical conditions.

Our surveys in both years encountered 2 different hydrographic and biogeochemical situations, as shown by the different temperatures, salinities, concentrations of SPM and chl $a$ and the phytoplankton composition. These differences were also reflected by the generally higher number of DGGE bands detected in both the FL and the PA bacterial communities in 2003 compared to 2002. In both years, inshore and offshore stations differed in temperature, salinity, SPM, POC, $\mathrm{chl} a$ and phaeopigments, and the distribution patterns of the FL and PA bacterial communities reflected these differences. The CCA results showed that these parameters exhibited close correlations to various bacterial subcommunities and thus appeared to be important in controlling their distribution in the German Bight. Noteworthy, in particular, are the close correlations of SPM and temperature to PA-Alphaproteobacteria in 2002 and of phaeopigments, SPM, bacterial abundance and PA-Bacteria in 2003 (Fig. 6A,B).

Our PCR assays yielded non-specific PCR amplifications. Non-specific amplifications by the Bacteriaspecific primer set have been reported previously (e.g. 
Selje \& Simon 2003, Stevens et al. 2005a). Amplification of chloroplast-derived 16S rRNA gene fragments in the PA bacterial community with this primer set is a general problem for samples containing phytoplankton cells. Non-specific amplification with primer ALF968r (Alphaproteobacteria) has also been reported by Rink et al. (2007) for samples from the East Frisian Wadden Sea and by Gich et al. (2005). The latter authors found amplification of Actinobacteria in freshwater samples. A recent re-evaluation of the specificity of the oligonucleotide probe ALF968, identical to the primer we used, in fact revealed $\sim 1700$ outgroup hits of this probe (Amann \& Fuchs 2008). Non-specific amplification of Deltaproteobacteria by the ALF968r primer predominantly occurred in the PA bacterial community at the shallow inshore stations (Stns 3 to 7 ) with high concentrations of SPM. Marine sediments contain high numbers of sulfate-reducing bacteria affiliated to Deltaproteobacteria (Llobet-Brossa et al. 1998, Musat et al. 2006), and also Myxobacteria which affiliate to this subclass of Proteobacteria as well (Stevens et al. 2005a). Hence, when these bacteria are present in samples in detectable numbers, their 16S rRNA genes are obviously amplified by this primer. In the FL bacterial community, no non-specific amplification occurred, indicating that this community did not include Deltaproteobacteria in proportions high enough to be amplified. In conclusion, a reliable assessment of the composition of PA-Alphaproteobacteria by the subclass-specific primer set was not possible. Our finding of non-specific amplification of the ALF968r primer has important implications for the interpretation of data obtained by fluorescence in situ hybridization (FISH) when using this oligonucleotide as a probe (ALF968). In habitats with high proportions of Deltaproteobacteria, these organisms may be included in the detection of Alphaproteobacteria, thus leading to an overestimation of this subclass.

The Bacteroidetes-specific primer set (Jaspers et al. 2001) also resulted in non-specific amplification in 3 out of 12 cases. Even though this is also a bias in the DGGE results, it appears not to be as critical as that with the Alphaproteobacteria-specific primer set, but it emphasizes the importance of sequencing of representative bands using group-specific primer sets in DGGE analyses.

These biases of non-specific amplification predominantly affected the DGGE banding pattern of the PA bacterial community obtained by the Bacteria-specific and Alphaproteobacteria-specific primer sets in 2003. The other banding patterns were only marginally affected. As we excluded the chloroplast-derived ribotypes from the binary code for the MDS analysis and CCA of the Bacteria-specific DGGE banding patterns of the PA bacterial community, and did not perform an MDS analysis of the Alphaproteobacteria-specific DGGE banding patterns of the PA bacterial community, this bias did not affect our MDS results or the CCA.

The PA bacterial communities detected by the Bacteria- and Bacteroidetes-specific primer sets had distinctly different compositions compared to those of the respective FL bacterial communities. These findings are consistent with previous reports from single stations in the same region (Gerdts et al. 2004, Stevens et al. 2005a). However, as in these 2 reports, we did not enumerate the PA bacteria and thus cannot directly assess their significance relative to that of the FL bacteria. PA bacteria have been enumerated in the SPM-rich East Frisian Wadden Sea by Lunau et al. (2006). In June and July of various years, the number of PA bacteria varied from 23 to $32 \%$ of total bacteria, and we assume that these values are representative for the inshore stations in general. Comparable values are not available for the offshore region of the German Bight. This region is characterized by low concentrations of SPM and aggregates (Riebesell 1991), and PA bacteria in such neritic seas usually constitute $<10 \%$ of total bacterial biomass and activity (Simon et al. 2002). Therefore, we assume that the number and proportion of PA bacteria at the offshore stations are lower than at the SPM-rich and shallow inshore stations of the German Bight.

\section{Composition of the bacterial communities}

The phylogenetic lineages we identified have previously been shown to constitute the bacterial communities in the German Bight to a great extent. Applying FISH, Eilers et al. $(2000,2001)$ found that, at Helgoland Roads, Bacteroidetes, Alphaproteobacteria and Gammaproteobacteria constitute 18 to 30,15 to 25 and 6 to $9 \%$ of DAPI-stainable bacteria, respectively, at various seasonal situations, including June. These groups also constitute the bacterial communities in the Wadden Sea to a great extent, with rather equal proportions in the FL fraction (each group 10 to $20 \%$ of DAPI-stainable bacteria) and PA fraction (each group 15 to $40 \%$ ) (Rink et al. 2008). Our results, in agreement with previous studies (Eilers et al. 2000, Zubkov et al. 2002, Selje et al. 2004, Stevens et al. 2005a), show that members of the Roseobacter clade and, in particular, of distinct subclusters (RCA, WM11-36, NAC11-7) are important components of the FL bacterial community in the North Sea. Two of these subclusters harbor photoheterotrophic roseobacters: the RCA cluster bacteriochlorophyll a-containing members (Giebel et al. 2011) and the NAC11-7 cluster proteorhodopsin-containing members (Riedel et al. 2010).

The FL subcommunity of the Bacteroidetes phylum exhibited a greater variability and richness than that of 
Alphaproteobacteria, as shown by the group-specific DGGE banding patterns and cluster analysis. The phylotypes were retrieved from the bands amplified by both the Bacteria- and Bacteroidetes-specific primer sets. The phylotypes affiliated to rather different clusters of the Sphingobacteria and Flavobacteria of the Bacteroidetes phylum, but in most cases were closely related to other phylotypes previously detected in the North Sea during phytoplankton blooms (Table 2, Fig. S4D; Zubkov et al. 2002, Stevens et al. 2005a,b, Rink et al. 2007, J. Pernthaler et al. unpubl.). Close relationships between phylotypes and isolates of the Bacteroidetes phylum and distinct phytoplankton and algal populations have been reported (Schäfer et al. 2002, Grossart et al. 2005, Rooney-Varga et al. 2005). Further, bacteria of this phylum are known to degrade complex organic polymers (Cottrell \& Kirchman 2000, Kirchman 2002). Therefore, it appears that the phylotypes affiliated to Bacteroidetes reflect more the specific substrate conditions related to the phytoplankton community of different growth stages and composition, and to other substrate sources at the various stations, than do the phylotypes of FL-Alphaproteobacteria. In support of this, the DGGE banding patterns of both subcommunities were negatively correlated (Fig. 6B).

Particles and suspended aggregates provide much more diverse micro-habitats than does the surrounding water (Simon et al. 2002). Depending on the given conditions and the water depth, they may include phytoplankton-derived organic matter as well as organic and inorganic matter resuspended from the sediment. Therefore, it is not surprising that the PA bacterial community contained more site-specific phylotypes reflecting local biogeochemical conditions than did the FL bacterial community. The PA bacterial community contained quite a few phylotypes affiliated to various clusters of the Bacteroidetes phylum (Table 3, Fig. S4D), but also various phylotypes affiliated to Alphaproteobacteria and Gammaproteobacteria and distinct from those in the FL bacterial community. The PA alphaproteobacterial phylotypes were related mainly to clusters of the Roseobacter clade which differ from those containing the FL bacterial phylotypes. Others affiliated to Sphingomonas and Acidiphilum aminolyticum (Table 2, Fig. S4A). The 2 Gammaproteobacteria phylotypes were detected in 2003 at Stns 6 and 7 in the North Frisian Wadden Sea and are closely related to phylotypes retrieved from the East Frisian Wadden Sea (Fig. S4B, Stevens et al. 2005b).

\section{CONCLUSIONS}

Our results show that the composition of PA and FL bacterial communities in inshore and offshore regions of the German Bight in the North Sea exhibits distinct differences. These differences were mainly detected in DGGE and MDS analyses and by CCA, applying Bacteria-, Bacteroidetes- and Alphaproteobacteriaspecific primer sets. The richness of the PA bacterial community detected by the Bacteroidetes-specific primers was greater than that of the FL bacterial community at all but 1 station, whereas the opposite was true for the bacterial communities detected by the Bacteria-specific primer set in 2003. In the previous year, only minor differences in the richness of both subcommmunities were detected. The bacterial phylotypes detected affiliate to phylogenetic lineages well-known from other studies in this region, including the Roseobacter clade of Alphaproteobacteria and several clusters of Gammaproteobacteria, Sphingobacteria and Flavobacteria of the Bacteroidetes phylum.

Acknowledgements. We appreciate the hospitality and cooperation of the captain and crew of RV 'Heincke'. We thank B. Kuerzel for dry-weight and chlorophyll analyses and A. Luek for phytoplankton and bacterial cell counts. This work was supported by the Deutsche Forschungsgemeinschaft (DFG) within the research unit 'BioGeoChemistry of tidal flats' (FG 432 TP5).

\section{LITERATURE CITED}

Alonso-Gutiérrez J, Lekunberri I, Teira E, Gasol JM, Figueras A, Novoa B (2009) Bacterioplankton composition of the coastal upwelling system of 'Ría deVigo', NW Spain. FEMS Microbiol Ecol 70:493-505

Alonso-Sáez L, Balagué V, Sá EL, Sánchez O and others (2007) Seasonality in bacterial diversity in north-west Mediterranean coastal waters: assessment through clone libraries, fingerprinting and FISH. FEMS Microbiol Ecol 60:98-112

Amann R, Fuchs B (2008) Single-cell identification in microbial communities by improved fluorescence in situ hybridization techniques. Nature Rev Microbiol 6: 339-348

> Baldwin AJ, Moss JA, Pakulski JD, Catala P, Joux F, Jeffrey WH (2005) Microbial diversity in a Pacific Ocean transect from the Arctic to Antarctic circles. Aquat Microb Ecol 41: 91-102

Becker GA, Dick S, Dippner JW (1992) Hydrography of the German Bight. Mar Ecol Prog Ser 91:9-18

Brinkhoff T, Bach G, Heidorn T, Liang L, Schlingloff A, Simon M (2004) Antibiotic production by a Roseobacter clade affiliated species from the German Wadden Sea and its antagonistic effects on indigenous isolates. Appl Environ Microbiol 70:2560-2565

Cotner JB, Biddanda BA (2002) Small players, large role: Microbial influence on biogeochemical processes in pelagic aquatic ecosystems. Ecosystems 5:105-121

Cottrell MT, Kirchman DL (2000) Natural assemblages of marine Proteobacteria and members of the CytophagaFlavobacteria cluster consuming low- and high-molecular-weight dissolved organic matter. Appl Environ Microbiol 66:1692-1697

Covert JS, Moran MA (2001) Molecular characterization of 
estuarine bacterial communities that use high- and lowmolecular-weight fractions of dissolved organic carbon. Aquat Microb Ecol 25:127-139

Crump BC, Armbrust EV, Baross JA (1999) Phylogenetic analysis of particle-attached and free-living bacterial communities in the Columbia River, its estuary and the adjacent coastal ocean. Appl Environ Microbiol 65: 3192-3204

Crump BC, Hopkinson CS, Sogin ML, Hobbie JE (2004) Microbial biogeography along an estuarine salinity gradient: the combined influences of bacterial growth and residence time. Appl Environ Microbiol 70:1494-1505

Dang HY, Lovell CR (2002) Seasonal dynamics of particleassociated and 18 free-living marine Proteobacteria in a salt marsh tidal creek as determined using fluorescence in situ hybridization. Environ Microbiol 4:287-295

Drebes G (1974) Marines Phytoplankton. Georg-ThiemeVerlag, Stuttgart

Eilers H, Pernthaler J, Glöckner FO, Amann R (2000) Culturability and in situ abundance of pelagic bacteria from the North Sea. Appl Environ Microbiol 66:3044-3051

Eilers H, Pernthaler J, Peplies J, Glöckner FO, Gerdts G, Amann R (2001) Isolation of novel pelagic bacteria from the German Bight and their seasonal contributions to surface picoplankton. Appl Environ Microbiol 67:5134-5142

Fandino LB, Riemann L, Steward GF, Long RA, Azam F (2001) Variations in bacterial community structure during a dinoflagellate bloom analyzed by DGGE and 16S rDNA sequencing. Aquat Microb Ecol 23:119-130

> Gerdts G, Wichels A, Döpke H, Klings KW, Gunkel W, Schütt C (2004) A long-term study of microbial parameters near Helgoland (German Bight, North Sea): historical view and future perspectives. Helgol Mar Res 58:230-242

Gich F, Schubert K, Bruns A, Hoffelner H, Overmann J (2005) Specific detection, isolation, and characterization of selected, previously uncultured members of the freshwater bacterioplankton community. Appl Environ Microbiol 71:5908-5919

Giebel HA, Brinkhoff T, Zwisler W, Selje N, Simon M (2009) Distribution of Roseobacter RCA and SAR11 lineages and distinct bacterial communities from the subtropics to the Southern Ocean. Environ Microbiol 11:2164-2178

Giebel HA, Kalhoefer D, Lemke A, Thole S, Gahl-Janssen R, Simon M, Brinkhoff T (2011) Distribution of Roseobacter RCA and SAR11 lineages in the North Sea and characteristics of an abundant RCA isolate. ISME J 5:8-19

González JM, Simó R, Massana R, Covert J, Casamayor E, Pedrós-Alió C, Moran MA (2000) Bacterial community structure associated with a dimethylsulfoniopropionateproducing North Atlantic algal bloom. Appl Environ Microbiol 66:4237-4246

Grossart HP, Levold F, Allgaier M, Simon M, Brinkhoff T (2005) Composition of bacterial communities associated with marine diatoms. Environ Microbiol 7:860-873

> Hewson I, Fuhrman JA (2004) Richness and diversity of bacterioplankton species along an estuarine gradient in Moreton Bay, Australia. Appl Environ Microbiol 70: 3425-3433

> Jaspers E, Nauhaus K, Cypionka H, Overmann J (2001) Multitude and temporal variability of ecological niches as indicated by the diversity of cultivated bacterioplankton. FEMS Microbiol Ecol 36:153-164

Kirchman DL (2002) The ecology of Cytophaga-Flavobacteria in aquatic environments. FEMS Microbiol Ecol 39: 91-100

> Lebaron P, Servais P, Trousselier M, Courties C and others (1999) Changes in bacterial community structure in sea- water mesocosms differing in their nutrient status. Aquat Microb Ecol 19:255-267

Llobet-Brossa E, Rossello-Mora R, Amann R (1998) Microbial community composition of Wadden Sea sediments as revealed by fluorescence in situ hybridization. Appl Environ Microbiol 64:2691-2696

Loewe P, Schmolke S, Becker G, Brockmann U and others (2005) Berichte des Bundesamtes für Seeschiffahrt und Hydrographie. Nr. 38/2005, Hamburg (www.bsh.de)

Lübben A, Dellwig O, Koch S, Beck M, Badewien TH, Fischer S, Reuter R (2009) Distributions and characteristics of dissolved organic matter in temperate coastal waters (Southern North Sea). Ocean Dyn 59:263-275

- Ludwig W, Strunk O, Westram R, Richter L and others (2004) ARB: a software environment for sequence data. Nucleic Acids Res 32:1363-1371

Lunau M, Lemke A, Walther K, Martens-Habbena W, Simon M (2005) An improved method for counting bacteria in samples with high proportions of particle-associated cells by epifluorescence microscopy. Environ Microbiol 7: 961-968

> Lunau M, Lemke A, Dellwig O, Simon M (2006) Physical and biogeochemical controls of microaggregate dynamics in a tidally affected coastal ecosystem. Limnol Oceanogr 51: 847-859

Musat N, Werner U, Knittel K, Dodenhof T and others (2006) Microbial community structure of sandy intertidal sediments in the North Sea, Sylt-Romø Basin, Wadden Sea. Syst Appl Microbiol 29:333-348

Muyzer G, de Waal EC, Uitterlinden AG (1993) Profiling of complex microbial populations by denaturing gradient gel electrophoresis analysis of polymerase chain reactionamplified genes coding for 16S rRNA. Appl Environ Microbiol 59:695-700

Muyzer G, Brinkhoff T, Nübel U, Santegods C, Schäfer H, Wawer C (1998) Denaturing gradient gel electrophoresis (DGGE) in microbial ecology. Molecular microbial ecology manual. Kluwer Academic Publishers, Dordrecht, p $1-27$

Nusch EA (1999) Chlorophyllbestimmung. In: von Tuempling W, Friedrich G (eds) Biologische Gewässeruntersuchung. G Fischer, Stuttgart, p 368-375

> Pinhassi J, Gómez-Consarnau L, Alonso-Sáez L, Sala MM, Vidal M, Pedrós-Alió C, Gasol JM (2006) Seasonal changes in bacterioplankton nutrient limitation and their effects on bacterial community composition in the NW Mediterranean Sea. Aquat Microb Ecol 44:241-252

> Porter K, Feig Y (1980) The use of DAPI for identifying and counting aquatic microflora. Limnol Oceanogr 25:943-948

> Reinthaler T, Winter C, Herndl GJ (2005) Relationship between bacterioplankton richness, respiration, and production in the southern North Sea. Appl Environ Microbiol 71:2260-2266

> Riebesell U (1991) Particle aggregation during a diatom bloom. II. Biological aspects. Mar Ecol Prog Ser 69: 281-291

> Riedel T, Tomasch J, Buchholz I, Jacobs J and others (2010) Constitutive expression of the proteorhodopsin gene by a flavobacterium strain representative of the proteorhodopsin-producing microbial community in the North Sea. Appl Environ Microbiol 76:3187-3197

> Rink B, Seeberger S, Martens T, Duerselen C, Simon M, Brinkhoff T (2007) Effects of a phytoplankton bloom in a coastal ecosystem on the composition of bacterial communities. Aquat Microb Ecol 48:47-60

Rink B, Martens T, Fischer D, Lemke A, Grossart HP, Simon M, Brinkhoff T (2008) Short-term dynamics of bacterial 
communities in a tidally affected coastal ecosystem. FEMS Microbiol Ecol 66:306-319

Rooney-Varga JN, Giewat MW, Savin MC, Sood S, LeGresley M, Martin JL (2005) Links between phytoplankton and bacterial community dynamics in a coastal marine environment. Microb Ecol 49:163-175

Sambrook J, Frisch EF, Maniatis T (1989) Northern hybridisation. In: Nolan C (ed) Molecular cloning: a laboratory manual, 2nd edn. Cold Spring Harbour Laboratory Press, New York, NY

Sapp M, Wichels A, Wiltshire KH, Gerdts G (2007) Bacterial community dynamics during the winter-spring transition in the North Sea. FEMS Microbiol Ecol 59:622-637

Schäfer H, Abbas B, Witte H, Muyzer G (2002) Genetic diversity of 'satellite' bacteria present in cultures of marine diatoms. FEMS Microbiol Ecol 42:25-35

Selje N, Simon M (2003) Composition and dynamics of particle-associated and free-living bacterial communities in the Weser estuary, Germany. Aquat Microb Ecol 30:221-236

Selje N, Simon M, Brinkhoff T (2004) A newly discovered Roseobacter cluster in temperate and polar oceans. Nature 427:445-448

Simon M, Grossart HP, Schweitzer B, Plough H (2002) Micro-

Editorial responsibility: Klaus Jürgens,

Rostock, Germany bial ecology of organic aggregates in aquatic ecosystems. Aquat Microb Ecol 28:175-211

Staneva J, Stanev EV, Wolff JO, Badewien TH and others (2009) Hydrodynamics and sediment dynamics in the German Bight. A focus on observations and numerical modelling in the East Frisian Wadden Sea. Cont Shelf Res 29: $302-319$

Stevens H, Brinkhoff T, Simon M (2005a) Composition and seasonal dynamics of free-living, aggregate- and sediment surface-associated bacterial communities in the German Wadden Sea. Aquat Microb Ecol 38:15-30

Stevens H, Stübner M, Simon M, Brinkhoff T (2005b) Phylogeny of Proteobacteria and Bacteroidetes from oxic habitats of a tidal flat ecosystem. FEMS Microbiol Ecol $54: 351-365$

Utermöhl H (1958) Zur Vervollkommnung der quantitativen Phytoplankton-Methodik. Mitt Int Verh Theor Angew Limnol 9:1-38

Zubkov MV, Fuchs BM, Archer SD, Kiene RP, Amann R, Burkill PH (2002) Rapid turnover of dissolved DMS and DMSP by defined bacterioplankton communities in the stratified euphotic zone of the North Sea. Deep-Sea Res II 49:3017-3038

Submitted: June 7, 2010; Accepted: January 17, 2011 Proofs received from author(s): April 18, 2011 